\title{
MANAGING THE HUMAN RESOURCES IN BEER INDUSTRY ${ }^{1}$
}

\author{
Dragić Živković ${ }^{2}$, Suzana Gučanin ${ }^{3}$, Zdravko Jež ${ }^{4}$
}

\section{Summary}

The human resources' management in business systems comprises a selection of goals, a policy determination, as well as planning, organizing, coordination and control of activities in the field of human resources, by taking over the management actions, in order to achieve the selected goals and to realize the purpose of the management function, as a sub-system of an organization's operation. The basic tasks of the human resources management are: planning, knowledge managing, improvement of work process and quality, control and evaluation of achievements. The paper's goal is to point out to a significance, which it has for its successful business, according to an analysis and description of the most important activities of the human resources' management, as theoretically, as well as practically, in a concrete business system.

Key words: management, human resources, beer, career development and business improvement.

JEL: J53, Q12

\section{Introduction}

The Decani charter, in the reign of Nemanjic dynasty, testifies on a fact that there was well-known obtaining malt from a grain and hopping, which confirms a fact that beer has been consumed at the court, in monasteries and private properties. The beginning of beer industry in Belgrade is related to the year 1872, when the industrialist from Pancevo, Ignjat Weifert, has started the construction of the first steam brewery, which had officially started with production in 1873, under the name ,The first steam brewery

1 This paper is a result of the research on the project No. 179028, financed by the Ministry of Education, Science and Technological Development of the Republic of Serbia, entitled "Rural labor market and rural economy of Serbia - diversification of income and reduction of rural poverty".

2 Professor Dragić Živković, Ph.D., Faculty of Agriculture Zemun, University in Belgrade, Nemanjina Street no. 6, 11080 Zemun, Serbia, Phone: +381 6387762 61, E-mail: d.zivkovic@agrif.bg.ac.rs

3 Suzana Gučanin, M.A., agro-economics manager, Faculty of Agriculture Zemun, University in Belgrade, Nemanjina Street no. 6, 11080 Zemun, Serbia, Phone: + 381112615315.

4 Professor Zdravko Jež, Ph.D., Faculty of Law, University Business Academy in Novi Sad, Geri Karolja Street no. 1, 21000 Novi Sad, Serbia, Phone: +381 63586 171, E-mail: jez@pravni-fakultet.info

EP 2014 (61) 1 (73-86) 
of Djordje Weifert", who had took over the management in that year. In December 1971 was produced a millionth hectolitre of beer, by which was marked an achievement, which had included, in that time, BIP at the top of the European beer producers. At the end of 1998, the BIP had done business as a joint stock company and had done an ownership transformation; the owners of its capital had become over 4000 of stockholders - physical persons, the Joint-stock Fund and PDI Fund, as well as other legal entities. In mid-2003, the capital ownership of $29 \%$ had gained the Republic of Serbia, on the bases of conversion of receivables. Aspiring to the best quality of its products and services, the BIP had won 160 golden medals, 7 crystal cups, 3 awards for quality and 3 trophies for top international quality, participating on many domestic and foreign selections, shows and appraisals.

\section{Method of work and data sources}

For proving the initial hypothesis of the paper was used different methods in order to satisfy basic methodological requirements - objectivity, reliability, generality and systematicity. In researches was made a turn to a business practice, by using the basic analytical and synthetic methods, and first of all, analyses, syntheses, inductions and deductions. Unavoidable is also using the statistical methods. In clarifying numerous questions were used methods and techniques of the documents analysis, as of a primary, as well as of a secondary matter - of already implemented researches, case studies, monitoring and testing. By applying these methods, it is possible to make a valid realization of scientific and social goal of the research.

While creating the paper, there was used local and foreign professional and scientific literature, the web-site of the Belgrade Beer Industry (BIP), discussions with employees in the company, various reports on business, as well as operational and accounting records.

\section{Sphere of work and equipment of enterprises with the means of production}

The scope of an enterprise's work mostly refers to the process of beer production, which divides in three basic phases: getting malt, getting a brewing malt and fermentation and "mellowing" of beer. The production capacities are located in Belgrade, Cacak and Leskovac. There are two organizational units: beer and malt factory, and juice and vinegar factory. The malt-house, which is located in Cacak, is the biggest factory in the Balkans, and it also produces kvass. The largest production of beer in Serbia $(351,888$ hl) was in 2008, and the lowest (236,640 hl) in 2011, and the beer realization, in hl, was described in the table 1 . 
Table 1. Realization of beer in $\mathrm{hl}$

\begin{tabular}{|c|l|l|r|r|r|}
\hline \multirow{2}{*}{ No. } & \multirow{2}{*}{ Brewery } & \multirow{2}{*}{ Location } & \multicolumn{3}{|c|}{ Beer realization in hl } \\
\cline { 4 - 6 } & & & $\mathbf{2 0 1 0}$ & $\mathbf{2 0 1 1}$ & \multicolumn{1}{c|}{$\mathbf{2 0 1 2}$} \\
\hline 1 & Apatinska & Apatin & $1,436.916$ & $1,714.037$ & $1,647.636$ \\
\hline 2 & MB & Novi Sad & N/A & N/A & $1.230,842$ \\
\hline 3 & Carlsberg Serbia & Celarevo & 589,805 & 585,418 & 959,159 \\
\hline 4 & Efes Serbia & Pancevo and Zajecar & 587,587 & 601,108 & 538,320 \\
\hline 5 & Trebjesa & Niksic & 535,899 & 508,279 & 557,887 \\
\hline 6 & BIP & Belgrade & 265,999 & 236,640 & 244,726 \\
\hline 7 & Jagodinska & Jagodina & 301,277 & 200,419 & 160,103 \\
\hline 8 & Brewery Nis & Nis & 204,677 & 72,523 & 101,805 \\
\hline 9 & Valjevska & Valjevo & 149,530 & 112,517 & 111,528 \\
\hline 10 & Industrijska & Zrenjanin & 76,953 & 56,050 & 41,608 \\
\hline 11 & Vršačka & Vrsac & 187,772 & 66,138 & 39,956 \\
\hline 12 & Pivara & Becej & 163,930 & 91,650 & 32,057 \\
\hline Total & & & $4,935.464$ & $4,487.272$ & $5,861.153$ \\
\hline
\end{tabular}

Source: Internal data.

The size of production by the assortment groups was given in the table 2 .

Table 2. Size of production by individual assortment groups (in hectolitres)

\begin{tabular}{|l|c|c|c|}
\hline \multicolumn{1}{|c|}{ Element } & $\mathbf{2 0 1 0}$ & $\mathbf{2 0 1 1}$ & $\mathbf{2 0 1 2}$ \\
\hline Beer & 265,999 & 236,640 & 244,726 \\
\hline Kvass & 7,929 & 8,991 & 10,335 \\
\hline Non-carbonated apple juice & 12,235 & 8,883 & 6,942 \\
\hline Alcohol vinegar & 18,687 & 22,621 & 23,818 \\
\hline
\end{tabular}

Source: Internal data.

The production, in valuable sense, was given in the table 3 .

Table 3. Total income in $000 \mathrm{RSD}$

\begin{tabular}{|l|c|c|c|}
\hline \multicolumn{1}{|c|}{ Element } & $\mathbf{2 0 1 0}$ & $\mathbf{2 0 1 1}$ & $\mathbf{2 0 1 2}$ \\
\hline Beer & $/$ & $/$ & $/$ \\
\hline Non-alcoholic beverages & $97,129.452 .00$ & $150,877.269 .00$ & $167,011.415 .00$ \\
\hline Kvass & $69,157.428 .00$ & $87,086.269 .00$ & $100,852.559 .00$ \\
\hline Vinegar & $83,947.958 .00$ & $112,109.409 .00$ & $120,278.512 .00$ \\
\hline Brewery's yeast & $4,866.263 .00$ & $5,509.94600$ & $5,530.595 .00$ \\
\hline
\end{tabular}

Source: Internal data.

This joint-stock company is a unique business system, structured by a functional and territorial-market principle, which realizes its business goals through: sales and marketing sector, human resources sector, project management sector, production sector and finances sector. The total number of employees is 530, of which 240 with secondary school background, and 80 with college and university qualification. The most of the totally employed is 41-45 years of age (116), and the smallest number is to 25 years of age (only 6). The highest average earning was realized in 2012, and the lowest in 2010. 


\section{Basic characteristics of human resources' management}

Managing employees, as the most important resources of the organization, is very complex and multi-dimensional process (Bogićević, 2004). The function of human resources' management mainly comprises the following activities:

- Business analysis, planning supply and demand for human resources, recruiting the candidates for vacancy jobs, selection of candidates for a specific job, training of employees, development of employees, evaluation of employees' performances, remuneration of employees, labour relations and collective negotiations, health and safety protection of employees and managing the process of leaving the organization.

The human resources function in the BIP organizes and conducts within four sectors:

1. Human resources sector,

2. Internal relations sector,

3. Development and education sector,

4. Operative sector of human resources.

All mentioned sectors are responsible for implementation of series of business activities. Planning the human resources usually conducts ones a year, along with possible modifications from time planning horizon point of view. The instruments in planning the human resources implement through different methods and techniques.

The BIP uses the human resources planning to set up a potential need for new staff. A job specification gives a review of necessary skills, characteristics and attributes which an individual should have, in order to do some job. There are necessary people with real skills, on every level of the organizational achievement, in order to fit the job into the company's business. Foreseeing demand is a process in which are made evaluations on number, quality and qualification of people who will be probably necessary to the organization, in the planned period.

The annual turnover index or fluctuation of employees sometimes is called a rate of decreasing number of employees, expressed in percentages, and it calculates by a formula: (number of those who leave a job during one year) / (average number of employees on duty during a year) x $100=$ rate of employees' decreasing number in $\%$.

The annual employees turnover index in the Belgrade Beer Industry $=(3 / 530) \times 100=0.57 \%$

The stability index bases on a number of persons, who could stay at work during some period. Often a number of employees, who had worked for a year, calculate as a percentage of persons on duty a year ago.

(number of employees with one year of work) / (number of employees a year ago) $\mathrm{x} 100=$ stability expressed in $\%$.

The stability index in the Belgrade Beer Industry $(B I P)=(25 / 533) \times 100=4.69 \%$. 
This index neglects the persons who found employments during a year and do not takes into consideration years of employment.

\section{Recruiting and selecting the human resources}

Recruiting is a phase of human resources' management, which purpose is to find the human resources, which have all necessary performances for engagement in the organization, at the same time interested for it. In order to come to the candidates selection, there must exist a document on systematization, by which anticipate the obligations of a perpetrator and key tasks, duties and responsibilities of the candidates, on the other hand. A document on jobs systematization is mandatory and statutory. Recruiting is a process, which aims to attract as more candidates as possible, in order a company to have a greater choice. The recruiting sources can be internal and external (Čamilović, Vujić, 2006). It is very important that a vacancy job is posted in adequate, clear and visible way in the organization. In the BIP the most represented is the internal recruiting source, because it is significantly cheaper and due to the possibility of employees' advancement and increase of their satisfaction with a job, which, finally, has better work results.

The most famous recruiting methods are: advertising, employees' credentials, recruiting by the employment agencies, recruiting via colleges and universities, recruiting via the internet. Each of these methods has its advantages, and also faults (Živković, 2012). In the Belgrade Beer Industry (BIP), seasonal workers employ via the employment agencies, and the workers on more responsible positions according to the employees' recommendations.

The selection is a process in which is made a selection among the available candidates for certain job and in which is made a decision on employment of someone who largely satisfies the job's requirements. The basic goal of the selection is to achieve as better as possible adjustment between the job requirements, conditions in which the job is done and the organization's goal, on one hand, and abilities and characteristics of a man, on the other and (Dessler, 2007). There are three groups of criteria, which in the selection process must be satisfied:

- Criteria which have to satisfy the selection methods,

- Criteria which have to be fulfilled by a candidate,

- Criteria which have to be fulfilled by the organization.

The selection methods and instruments for evaluation of the candidates are: A candidate's documentation - situations vacant, CV, questionnaire, interview, psycho-tests, recommendations, medical reports, other instruments of selection and evaluations. The $\mathrm{CV}$ often serves as a ground for the interview preparation, while the $\mathrm{CV}$ is a document which contains the information on a candidate, necessary to an employer. For collecting data on abilities and personal characteristics of candidates, the widest use and the greatest significance have tests and the interview (Đorđević, Pavić, 2011).

The test represents a measuring instrument, by which people compare by some characteristic, as a measuring subject. There are various types of tests, which divide in two basic groups: 
- Psychological tests: capability tests, personality tests, tests of interest, proficiency tests, and

- Tests related to a job: tests of work samples, tests of gaining skills ability, probation.

In the BIP do not apply any of the stated tests, but only the tests to assess the knowledge of health and safety at work.

The interview represents the selection instrument, which goal is to predict a business performance of candidates, according to their verbal responses (Drucker, 2005). There apply different types of the interview, which group according to different criteria, by:

- Form, i.e. a level of structure: structural, semi-structural and non-structural,

- Number of participants: individual, sequential, panel and group,

- Role in the selection process: preliminary, diagnostic and admission,

- Type of questions: situational and behavioural.

In the BIP is represented a team interview, where, besides the experts for interviewing, also participate the potential future colleagues.

Socialization of newly-employed is a process in which a newly-employed worker adjusts to a working environment conditions and to business rules of the whole organization. This is a two-way process in which participate both the organization and the employees. An employee is introduced to a job he is going to do, with work tasks, within a description of his job, with colleagues he is going to work with, with the entire organization business, values and attitudes of organizational culture, background of the organization, business rules, benefits and obligation of the employees. For the socialization process are responsible, as a department for human resources, as well as a department in which the newly-employed person takes up employment. The socialization process ends at the moment when an employee develops a sense of belonging to the organization. In the BIP are two-months-lasting programs of complete enlightenment to orientation, which introduce the newly-employed persons with the company and its values, vision, goals and strategy.

When it is about the employees' training, the previous practice has shown which training and developmental programs ensure the best results, depending on a type and a level of knowledge. Identification of needs for training and development of employees realizes at three levels:

- At the organization level,

- At the individual job level,

- At the individual level, as well as at the groups level.

The goal of training is: to form an effective and quality team, how to evaluate personal characteristics of some team members regularly, how to improve behaviour and mutual communication between the team members and how to provide quality and efficient functioning of the whole team. In practice uses the most 5 training models of employees: functional model, customer model, stencil model, model of corporative university 
and virtual model. The BIP tends to provide to its employees, the combination of developmental activities, mostly composed of $70 \%$ of tasks and projects at work, $20 \%$ of couching and $10 \%$ of training. During 2012, the employees had attended many onemonth-lasting trainings, after which had got a certificate. The training is assigned for trainees - younger people, with university education - giving them a questionnaire on employees training with numerous questions.

The performance or output can be: job quality, job quantity, acquaintance with a job, interpersonal impact, responsibility, ability and interest to do a job successfully. The employees put note on what is expected of them and what are the realized results. The performances evaluation aims to increase work motivation and to determine a plan of future development of the employees. In evaluation of the performances of the employees use different methods, like: scale assessment, checklists, common ranking, method of comparison in pairs, group ranking, critical event, description, review of fields, managing goals etc. The common mistakes which appear in evaluation are: hallo effect, mild and rigorous evaluation mistakes, central tendency mistake etc. In the BIP is developed software for internal evaluation after the methodology $360^{\circ}$, by which create developmental and training programs, totally adjusted to individual needs of the employees. In the BIP pays special attention to development of employees, as a need of permanent development of human resources, i.e. permanent acquirement of new knowledge and abilities, not only of the newly-employed staff, but of all employees. Practically apply numerous education methods (Đorđević-Boljanović, 2009), which can group:

- Methods of education at work (individual instructions and job rotation, professional practice, training period, mentoring and student practice) and

- Methods of education outside of work, as: lectures, audio-visual technique, programmed learning, learning by computers, conferences and discussions, training in simulated working conditions, case methods and other methods.

Great attention pays to staff development, while the employees have a possibility to progress and to improve professionally.

\section{Systems of earnings (salaries) and strategic aspects of payments}

The earning (personal income, salary) represents a money which the employees earn working to an employees, who pays them the earning. A term earning:

- To an employer - means the total amount which he has to pay monthly for an employee - "super gross income".

- To an employee - means the amount which monthly gets "payment to payee in person" as his salary - "net income"

- To legislator - means the amount somewhere between these two amounts - "gross income".

In the BIP, the employees have a right to an adequate earning, which determines in accordance to the law, a collective labour contract and a labour contract. The employees in the BIP retail stores realize a right on earning, other incomes and reimbursement of costs, 
based on special conditions, i.e. based on a percentage of sold goods within a month, in accordance with the special contracts, signed with the employee. The earning for the work and time spent at work in the BIP consists of:

- Basic earning,

- Part of earning for a labour output,

- Increased earning.

A part of earning on the basis of labour output consists of fixed and variable part. An employee has a right to increased earnings in the following cases: overtime work $28 \%$, night shifts $40 \%$, for work on holidays (day off) $140 \%$, shift work $26 \%$, on basis of time spent at work for each full year of work realized in labour relation $0.5 \%$, for work in a second shift $5 \%$.

The example of earning calculation in J.S.C. "BIP"- Belgrade in restructuring was given in annex of the contract on employee's work with secondary school background, economic technician (table 4).

Table 4. Calculation of earning

\begin{tabular}{|c|c|c|c|c|}
\hline Element & $\begin{array}{l}\text { Coefficient of } \\
\text { earning }\end{array}$ & $\begin{array}{l}\text { Amount of basic } \\
\text { and percentages of } \\
\text { increased earning }\end{array}$ & $\begin{array}{c}\text { Amount } \\
\text { reduced for } \\
\text { taxes and } \\
\text { contributions }\end{array}$ & Gross amount \\
\hline Basic earning & 1.55 & $19,320.00$ & $29,946.00$ & $41,379.97$ \\
\hline Night shifts & & $30 \%$ & & \\
\hline Shift work & & $26 \%$ & & \\
\hline Holidays work & & $120 \%$ & & \\
\hline Overtime work & & $26 \%$ & & \\
\hline Materialized labour & & $0.5 \%$ & $3,443.79$ & $4,758.70$ \\
\hline \multicolumn{5}{|l|}{ Variable } \\
\hline $\begin{array}{l}\text { Hot meal in amount of } \\
20 \% \text { of minimal earning }\end{array}$ & & & $3,864.00$ & $5,512.13$ \\
\hline \multicolumn{5}{|l|}{ Recourse } \\
\hline Total gross earning & & & & $51,650.80$ \\
\hline
\end{tabular}

Source: Internal data.

The earnings based on performances are more and more popular form of earnings among young people of high education, while they take into consideration a contribution of individuals in achieving the results and they comprise short-term and long-term stimulations. The short-term stimulations aim to instigate the employees to achieve defined short-term results, as: pay rises, bonuses, special premiums, individual and group stimulations. For a period longer than a year are given long-term stimulations, which include: share in ownership, options, gifts in shares under specific conditions, right to profit due to increase of a share price and phantom shares. In the BIP, the managers reward only according to a realized output, through motivation for achieving 
the top results at work and commitment to a company. In the BIP does not apply monitoring of individual work results, because the company is in restructuring. In this company, the employees primarily motivate with the earnings and with advancement at work, by paid vacations, workers-sports games, etc.

\section{Labour relations and collective negotiations}

The labour relations have been processed in the law on labour and it has studied it as a law relation. The legal regulatory rules in the field of work and labour relations comprises numerous laws: law on labour, law on employment and insurance in case of unemployment, records in labour fields, retirement and disability insurance, safety and health at work, etc. The most important legal act by which determine and realize rights, obligations and responsibilities in mutual relations between the employers and the employees, is the Law on Labour, which applies to all employees in government and public services and companies. A labour contract is a document on which bases the labour relation between an employer and an employee, and precise their mutual rights and obligations and it is in written form. According to the law on labour, the employer should not illegally discriminate a worker on the following grounds: sex, marital status, origin, ethnicity, disability, membership in a trade union, part time work or if a worker is ex-convict, etc. The employees which work for the employer (physical person, i.e. an entrepreneur) have a right, as the other employees, to a union organizing according to a clause 5 of the law on labour. The employer is obliged to provide some costs, without compensation, to the management of a representative union, and to the union representatives also a fund of monthly paid hours for performing their functions. In the BIP there are two unions: independent ASNS and the Independent Union. The independent ASNS has 20 members, while the independent union has 293 members; it is representative and has been entered in the Register of Trade Unions. The union "BIP" is a collective member of the Independent Union of those employed in agriculture, food, tobacco industry and water management of Serbia and is a member of the Belgrade Association of Independent Trade Unions. This union is a legal entity and it engages itself on realization and protection of members' rights based on work. In regard to the previously mentioned, the collective negotiation is an organized process, which preceds to signing the collective contracts between an employer and the employees. The employees are led by the representative union of the organization and the purpose of negotiation between the unions, i.e. the employees and the employers' association, analyses through signing the collective labour contract. The most important elements of the collective negotiation process are: negotiating behaviour, negotiating power, subjects of the negotiation and termination of the negotiations. By the collective labour contract solves many issues, and it has a legal effect for all persons who belong to a certain group (a collective or some organization), which had signed the contract. 


\section{Health, safety and welfare of employees}

A care on health protection and safety at work represents one more very important activity of human resources management. Only healthy and safe employees can be satisfied with their position in the organization, and thereby are successful in their work. A purpose of safety at work is a prevention of occupational injuries and professional diseases, i.e. making conditions to prevent the injuries. The firms are obliged to provide work in safe conditions, as well as to train the employees for work in a safe manner (Živković et al., 2013). Employees should be aware of the hazards in their workplace and ways to protect from them. On the other hand, the employees are obliged to do their jobs in a safe manner and in accordance with the rules of safety at work, as well as to use legitimate protective equipment. In the BIP was implemented a program of workers training in the field of fire protection, which contributes to safety improvement and health at work, along with respect of necessary procedures for safe work on electrical-energy facilities and in offices. The training carries out every third year, while practical and theoretical examination carry out every year. One of the most significant measures is a compulsory use of PPE (equipment), which the workers get every year, which have caused a small number of injuries at work. In this company carry out regularly and according to a plan, the programs of health protection, rehabilitation and recreation of workers, which include a systematic medical examination, spa treatments, recreational excursions and sports-recreational activities, aiming to increase psychophysical abilities of the employees, as well as the other programs for liquidation and minimization of emergencies' and natural disasters' consequences.

\section{Complaints, discipline, retention of employees and leaving the organization}

The right to appeal is guaranteed by the Constitution and it falls into the basic civil rights. A discipline is regulation of human activities due to realization of controlled results and it includes: managerial, team and self-discipline. Each company have rules which have to be obeyed, and which refer to different types of behaviour, for which, if not obeyed, follows typical forms of penalties. In the BIP apply all determined forms of penalties, in a way that a complaint receives in a legal department and there makes a decision if an employee will be penalized or not and decides on a type of a penalty. Key characteristics of complaints procedure are righteousness, procedural steps and speed of settlement. The employees' retention is a service which decreases fluctuation on key positions, in order it identifies the employees where there is more likely they will leave the company within a year. The reasons for which people voluntarily leave the organization are: external factors, functional turn, attraction and denial factors. In the BIP, the employees keep by growth of an employee's life standard, and better possibilities to improve in a career.

Leaving the organization can be defined as a termination of membership of an employee employed in the organization. Leaving the company by an employee can be willingly or unwillingly by an employer. Forms of willingly leaving of the company are: labour relation termination by an employee and retirement. The forms of unwillingly leaving 
of the company are: labour relation termination by an employer and laying-off the employees as a manpower redundancy. During past years, in fast changes conditions, the companies have faced a need to manage systematically the issue of employees' fluctuation. On a fluctuation rate influence the factors like: devotion of the employees to the company, stress at work and a level of education. On the other hand, on longer staying of the employees in the organization affect the factors, like; marital status, a larger number of dependents, duration of years of employment and age. In the BIP, the employees leave the organization due to personal motives, like better salaries, better working conditions, possibility for advancement in some other company, less distance to work, etc.

Pension (forms of pensions) is a monthly compensation to which an individual has a right on the basis of a retirement, disability and death insurance, under the conditions determined by the law. Depending on the conditions under which the retirement was gained, the pension can be an old-age pension, disability pension or a family pension. The BIP had founded the first voluntary pension fund in Serbia and had been licensed by the National Bank of Serbia in 2001. The Voluntary Pension Fund represents a simple and available way of saving, which has been under multiple supervision and control of the National Bank of Serbia. To a voluntary pension fund's pension does not affect duration of the years of employment, and its negotiation does not terminate a right to a state pension. In the voluntary pension funds, the whole fund's possessions are only the fund members' ownership, proportional to their investments. In the BIP, the employer is obliged to pay off to an employee: a dismissal wage, reimbursement of funeral expenses in case of death of an immediate family, compensation for injuries at work or professional diseases, jubilee awards to the employees for 10, 20, 30, 35 and 40 years of continuous work, solidarity for help in case of child's birth and so on.

Benefits represent material compensations by which the companies indirectly motivate the employees. A right to use benefits is not regulated by the contract between personnel and the employers, but it acquires from belonging to the company and, through them the firms try to attract and keep quality and competent people. The benefits represent concessions above a base salary and incentive earnings and their height does not depend on the performance of employees. The benefits increasingly become a matter of strategy of the company aiming to compete with a competition. All benefits can be classified in three groups: safety and health benefits, free time benefits and services to employees.

Table 5. Types of benefits

\begin{tabular}{|l|l|l|}
\hline \multicolumn{1}{|c|}{ Types of benefits } \\
\hline \multicolumn{1}{|c|}{ Safety and health benefits } & \multicolumn{1}{c|}{ Free time benefits } & \multicolumn{1}{c|}{ Services to employees } \\
\hline Retirement insurance & Vacations & Scholarships \\
\hline Health insurance & Holidays & Employees' credits \\
\hline Life insurance & Excused absences & Hot meals \\
\hline Sick leave & Paid leaves & Company's cars \\
\hline Social security & Paid leave for professional training & Professional cloths \\
\hline
\end{tabular}




\begin{tabular}{|l|l|l|}
\hline \multicolumn{2}{|c|}{ Types of benefits } \\
\hline Safety and health benefits & \multicolumn{1}{|c|}{ Free time benefits } & \multicolumn{1}{c|}{ Services to employees } \\
\hline Employer's liability insurance & Paid time of additional education & Transport \\
\hline Dismissal wages etc. & & Legal services \\
\hline & & $\begin{array}{l}\text { Care for children and old } \\
\text { persons }\end{array}$ \\
\hline & & $\begin{array}{l}\text { Recreation and health } \\
\text { programs }\end{array}$ \\
\hline & $\begin{array}{l}\text { Unpaid leave due to family } \\
\text { issues }\end{array}$ \\
\hline
\end{tabular}

Source: Internal data.

With realization of benefits programs and by solidarity payments, the company shows understanding for different needs of employees.

\section{Conclusion}

According to the previous review can determine that the BIP in its supply has four basic production programs: beer production, production of non-alcoholic beverages, production of brewing malt and alcoholic vinegar. Besides, it has also the additional program, which encircles the production of dried brewing yeast, malt sprouts, and it has a utility which comprises hospitability - beer-houses retail, wholesale, malting services, transport, pouring and technical-technological services. The activities in the BIP can divide into 3 programs:

- Production - it realizes according to regulated and determined technological procedure. The equipment, devices and lines for beer production are in good shape, and it is about the program SIMATIK 5, which provides measuring regulation and equipment in order to track and control the production process,

- Bottling (pouring the products) - is realized on the line KRONES, which has computerized machines and equipment. The beer durability achieves by pasteurization. Pouring of non-alcoholic beverages realizes on the line KOSME, which devices and equipment are computerized and supplied by tracking system and a system for control of pouring process,

- $\quad$ Packing products is adjusted to requirements of marketing and market. There is installed equipment for packing the products and different packing dimensions, with different number of units and label marked, on which are all necessary information regulated by the standard.

The important characteristic of the company is its territorial dislocation. The human resources management is a business function of the company, where all its activities are analyzed: planning, recruiting selections, socialization, directing, training and education, evaluation of employees' performances, their advancement and motivation, care of health and safety to manage career and laying-off - retirement of employees. Although all activities are important, there was noticed that in the BIP, the process of employees' selection and their education, as well as their further education and career development, have the greatest significance. The BIP has defined key fields of results and output standard 
for every organizational level. The Belgrade Beer Industry pays a special attention to personnel development and their additional education, taking into consideration that knowledge is the essential resource, which will make the difference between successful and unsuccessful ones. There is also necessary to make the workplaces rationalization, in sense of determination of deficiency and redundancy of labour in some sectors, as well as solving all problems. It is necessary to set the system of examinations for all employees, on annual basis, and to evaluate work of the employees, in order to set up the models of team work. There was determined by the analysis that it is not enough developed a leadership, that the employees are not, in every organizational unit, acquainted with the essence of changes, that should develop skills of mid-level management through internal education, that should train new associates and to develop goals-orientation, not only activities-orientation, to intensify the communication with the employees and to introduce rules of information transmission and to introduce the adequate awards and valuations for the achieved results.

\section{Literature}

1. Bogićević, V. (2004): Menadžment ljudskih resursa, Centar za izdavačku delatnost Ekonomskog fakulteta, Beograd.

2. Čamilović, S., Vujić, V. (2006): Osnove menadžmenta ljudskih resursa, TekonTehnokonsalting.

3. Dessler, G. (2007): Osnovi menadžmenta ljudskih resursa, Data status, Beograd.

4. Drucker, P. (2005): Upravljanje u novom društvu, Adižes, Novi Sad.

5. Đorđević, J., Pavić, Ž. (2011): Osnove menadžmenta ljudskih resursa, Univerzitet Singidunum, Beograd.

6. Đorđević Boljanović, J. (2009): Menadžment znanja, Data status, Beograd.

7. Živković, D. (2012): Menadžment ljudskih resursa, Univerzitet u Beogradu, Poljoprivredni fakultet.

8. Živković, D., Rajić, Z., Jelić, S., Jandrić, M. (2013): Organizational and economic characteristics of production and meat processing company, Economics of Agriculture, vol. 59, no. 2, pp. 419-426.

9. http://bip.rs/\#

10. http://sindikat-bip.com/ 


\title{
UPRAVLJANJE LJUDSKIM RESURSIMA U INDUSTRIJI PIVA
}

\author{
Dragić Živkovič́, Suzana Gučanin ${ }^{6}, Z$ Zdravko Jež̆ ${ }^{7}$
}

\section{Rezime}

Menadžment ljudskih resursa u poslovnim sistemima obuhvata izbor ciljeva, utvrđivanje politika, kao i planiranje, organizovanje, koordinaciju i kontrolu delatnosti u području ljudskih resursa, i to preuzimanjem upravljačkih akcija radi postizanja izabranih ciljeva $i$ ostvarivanja same svrhe upravljačke funkcije kao podsistema funkcionisanja organizacije. Osnovni zadaci menadžmenta ljudskih resursa su: planiranje, organizovanje, upravljanje znanjem, poboljšanje procesa i kvaliteta rada, kontrola i vrednovanje dostignuća. Cilj rada je da se na osnovu analize i deskripcije najvažnijih aktivnosti menadžmenta ljudskih resursa, kako teorijski, tako i na praktičnom primeru u konkretnom poslovnom sistemu, ukaže na značaj koji on ima za njegovo uspešno poslovanje.

Ključne reči: menadžment, ljudski resursi, pivo, razvoj karijere i unapređenje poslovanja.

5 Prof. dr Dragić Živković, Poljoprivredni fakultet Zemun, Univerzitet u Begoradu, Nemanjina 6, 11080 Zemun, Srbija, Telefon: +381 6387762 61, E-mail: d.zivkovic@agrif.bg.ac.rs

6 Suzana Gučanin, master menadžer agroekonomije, Poljoprivredni fakultet Zemun, Univerzitet u Begoradu, Nemanjina 6, 11080 Zemun, Srbija, Telefon: + 381112615315

7 Prof. dr Zdravko Jež, Pravni fakultet, Univerziteta Privredna akademija u Novom Sadu, Geri Karolja 1, 21000 Novi Sad, Srbija, Telefon: +381 63586 171, E-mail: jez@pravni-fakultet.info 